\title{
Review: Potential Effectiveness of Paleolithic Nutritional Interventions in Treatment of Gynecological Cancers
}

\author{
Rumsha Fatima ${ }^{1 *}$ and Hadia Fatima ${ }^{2}$ \\ ${ }^{1}$ Atta-ur-Rahman School of Applied Biosciences, National University of Sciences and Technology, Islamabad, Pakistan \\ ${ }^{2} \mathrm{MBBS}, \mathrm{FCPS}$ in Radiation Oncology, Pakistan
}

Submission: January 12, 2021; Published: January 29, 2021

*Corresponding author: Rumsha Fatima, Atta-ur-Rahman School of Applied Biosciences, National University of Sciences and Technology, Islamabad, Pakistan

\begin{abstract}
Background: Limited research has been performed for treating gynecological disease conditions using paleodiet intervention. It is in demand to conduct many randomized controlled trials to prove its effectiveness. This review indicates one of the most important literature gaps in gynae-oncology. Paleo nutrition has recently emerged as a treatment option in conditions related to gynecology, and such potential benefits are indicated in few short-term clinical trials and case reports related to gynecological cancers and malignancies.
\end{abstract}

Objective: This meta-analysis is aimed to address the importance of nutritional intervention, with emphasis on paleo nutrition, in treatment of gynecological cancers, pre-malignancy conditions, and post-operative recovery in women.

Materials: PubMed, Scopus, SciPubs, Mayo Clinic, Cochrane Library, Covance Laboratory and ASRM databases were used for collecting data in the form of case reports, research articles, reviews, clinical trials, journals, and books.

Design: Out of 400 publications, 7 are shortlisted for their relevance to gynecological oncology and paleo nutrition interventions. Case reports and short-term clinical trials between year 2000-2020 are included for comparative analysis of Paleodiet and its variants with other nutritional interventions.

Results: There is no scientific data that has been reported on genetic and molecular impacts of paleo-nutrition on gynecological cancers. Clinical reports suggest significant improvement through paleodiet intervention in anthropometric markers and metabolism in pre-treatment and post-treatment examination of patients of gynae-oncology. Very limited data is available for comparative analysis of paleodiet and other dietary interventions.

Conclusion: Paleo nutrition is an under-researched future intervention and has a potential to impact treatment strategies for gynecological patients. A large volume of randomized controlled trials for each ethnic group can help manage the cancer burden globally.

Keywords: Paleo-Oncology; Paleo Diet; Gynecological Cancers; Discordance Hypothesis; Meta-analysis

\section{Introduction}

Nearly $20-88 \%$ patients of gynecological oncology present with symptoms of malnutrition [1]. Whereas $20 \%$ deaths in gynecologic cancers are attributed to metabolic stress and progressive nutritional decline [2]. Different from malnutrition, cancer cachexia related metabolic stress cannot be easily reversed with caloric intake alone [3]. According to the United States Cancer Statistics, about 94,000 women in the US were diagnosed with gynaecologic cancer annually, between 2012 and 2016 [4]. The latest figures provided by the World Health Organization, mark cervical cancer as the fourth most common cancer type in women. Facts sheet discusses various indices including cervical cancer 'incidence' recorded in 2018 which numbered 570,000 women globally who were diagnosed with it, and 'fatality' of 311,000 women who died with the disease [5].

Research focus has now shifted as scientists are navigating through the history of cancer in ancient skeletal preserves. Human Papilloma Virus mediated being a major cause of uterine cervix, was noted to be likely present in ancient Dakhleh as this virus has 


\section{Cancer Therapy \& Oncology International Journal}

evolved and formed an etiological link to reproductive cancers [6]. In this regard, field of paleo-oncology has provided convincing evidence of socio-cultural, environmental, and biological factors as contributors of oncogenic mutations \& epimutations which resulted in emergence of various types of malignancies [7]. Cancer is a modern disease as well as part of our legacy [8], as suggested by the archeological studies in fossil remains of animals, humans, and their ancestors of Paleolithic period (approximately 2.5 million-10,000 years ago). These studies show how cancer has majorly affected the populations who have adopted industrial lifestyles, quite different from the routines of their ancestors, which were based on farming practices and paleo diet [9]. Therefore, the multiple diet patterns of our Palaeolithic ancestors, of diverse ethnic and geographic groups, varied considerably in composition and proportion of macronutrients from vegan and non-vegan food sources [10].

\section{Methods}

Search Strategy: Due to limited data and literature available on paleo-gynae oncology between 2000-2020, a single case report, clinical trial results and two meta-analysis articles of randomized clinical trials were included. Other articles, clinical trials and clinical reports were indirectly related to the impacts of paleodiet in treating gynae-oncology patients. These were included in the review for their emphasis on treatment of symptomology, indirectly related to gynecological conditions and diseases, using paleodiet. Reviews on healthy subjects and volunteers with no previous history of disease symptoms or risks were excluded. Due to insufficient evidence, cross over trials were also excluded.

\section{Results}

\section{Efficacy of Paleo Nutrition}

A customized paleo-diet intervention help cured a female with recurrent cervical intraepithelial neoplasia without hysterectomy. No other supplementary treatment or nutrient intervention was reported to have been adopted in the procedure. No side effects have been reported in 26 months long dietary treatment [11]. Paleodiet variants were proved beneficial, for treating obesity in menopausal women, as compared to other dietary interventions in short-term randomized controlled trial [12]. Paleo-vegan, Indian variant of paleo nutrition, proved to enhance insulin sensitivity in diabatic and endocrine abnormalities [13].

Table 1 summarizes scientific evidence of paleodiet interventions used to treat gynecological cancers and premalignant conditions. Dietary components which were customized for specific size of experimental groups indicate that only natural food sources and enriched with macronutrients of paleolithic times are present in the diet plan. Table 2 shortlists clinically tested paleodiet variants used to treat various conditions related to gynae-oncology.

Table 1: Paleo-nutrition intervention in treatment of various gynaecological cancers and pre-malignancies, including case report, clinical trial and meta-analysis of randomized clinical trials. Components of customized paleo-diet interventions include all natural food sources and no industrialized processed foods are included.

\begin{tabular}{|c|c|c|}
\hline Dietary Plan & Components & Sample size \\
\hline $\begin{array}{c}\text { Paleolithic-Ketogenic } \\
\text { Diet (26 months) [11] }\end{array}$ & $\begin{array}{c}\text { "Animal fat-meat based diet (Red and fatty meats and a regular intake of offal } \\
\text { from cattle and pork) with a fat: protein ratio of about 2: 1 (in grams). Cereal } \\
\text { grains, dairy, food additives \& dietary supplements were excluded. < 30\% intake } \\
\text { of vegetables \& fruits. Honey \& coffee consumption was moderate." }\end{array}$ & $\begin{array}{c}\text { Case Report of a patient with } \\
\text { recurrent cervical intraepithelial } \\
\text { neoplasia (CIN) }\end{array}$ \\
\hline $\begin{array}{c}\text { Paleo-Type Diet (PD) } \\
\text { (2 years of randomized } \\
\text { controlled trials) [12] }\end{array}$ & $\begin{array}{c}\text { "30\% of energy intake from protein, 40\% fat \& 30\% Carbs from lean meat, fish, } \\
\text { eggs, vegetables, fruits, berries and nuts, avocado, rapeseed \& olive oils. Dairy } \\
\text { products, cereals, added salt, refined sugar \& fats were excluded." }\end{array}$ & $\begin{array}{c}35 / 70 \text { postmenopausal women, } \\
\text { non-smokers as per inclusion } \\
\text { criteria }\end{array}$ \\
\hline Paleo-Vegan Diet [13] & $\begin{array}{c}\text { "No animal-based foods, low carbohydrate and lean protein of 30-35\% daily } \\
\text { caloric intake, 45-100 g fiber diet from non-cereal, plant-based sources." }\end{array}$ & Meta-analysis \\
\hline
\end{tabular}

\section{Clinically Used Variants of Paleo Nutrition}

Table 2: Paleodiet and its variants scientifically proved to have been beneficial in treating various conditions related to gynae-oncology.

\begin{tabular}{|c|c|c|c|c|}
\hline Nutritional Intervention & Scientific Evidence & Benefits & Side Effects & Limitations \\
\hline 1. Paleo-Keto Diet & $\begin{array}{c}\text { Cessation of recurrent cervical } \\
\text { intraepithelial neoplasia without } \\
\text { hysterectomy } \\
{[11]}\end{array}$ & $\begin{array}{l}\text { Sustained ketosis in carb-free diet, } \\
\text { Healthy weight loss, } \\
\text { Reduced inflammation level indi- } \\
\text { cated by CRP test }\end{array}$ & $\begin{array}{l}\text { Case report of the } \\
\text { patient declared no } \\
\text { side effects }\end{array}$ & $\begin{array}{l}\text { Long term diet plan } \\
\qquad(26 \text { months })\end{array}$ \\
\hline $\begin{array}{l}\text { 2. Paleolithic-Type Diet } \\
\text { (PD) }\end{array}$ & $\begin{array}{l}\text { Long term effects in obese post- } \\
\text { menopausal women } \\
{[12]}\end{array}$ & $\begin{array}{l}\text { Decreased fat mass \& waist cir- } \\
\text { cumference, } \\
\text { Significant decrease in triglyceride } \\
\text { levels related to increased insulin } \\
\text { sensitivity }\end{array}$ & & $\begin{array}{l}\text { Poor adherence to } \\
\text { the target intake of } \\
\text { protein }\end{array}$ \\
\hline $\begin{array}{l}\text { 3. Paleolithic Vegan } \\
\text { Diet }\end{array}$ & $\begin{array}{c}\text { For Diabesity and endocrinopa- } \\
\text { thies [13] }\end{array}$ & $\begin{array}{l}\text { Healthy weight loss, Improved gly- } \\
\text { caemia \& adipo-cytokine profiles }\end{array}$ & $\begin{array}{l}\text { concerns related to } \\
\text { micronutrient defi- } \\
\text { ciency were present }\end{array}$ & \\
\hline
\end{tabular}




\section{Cancer Therapy \& Oncology International Journal}

Table 2 summarizes the health advantages obtained for different patients of gynaecological complications through customized paleodiet variants. Paleo-keto combination proved successful in complete cessation of cervical neoplasia without hysterectomy or any supplementary dietary treatments [11].
Palaeolithic Type diet (PD) used in randomized controlled trial for post-menopausal obese women helped reducing risks associated with metabolic syndrome [12]. Vegan variant of paleo diet proved beneficial for diabetes related malfunctioning of endocrine hormones [13].

\section{Relationship between Metabolic Syndrome (MetS) \& Gynecological Cancers}

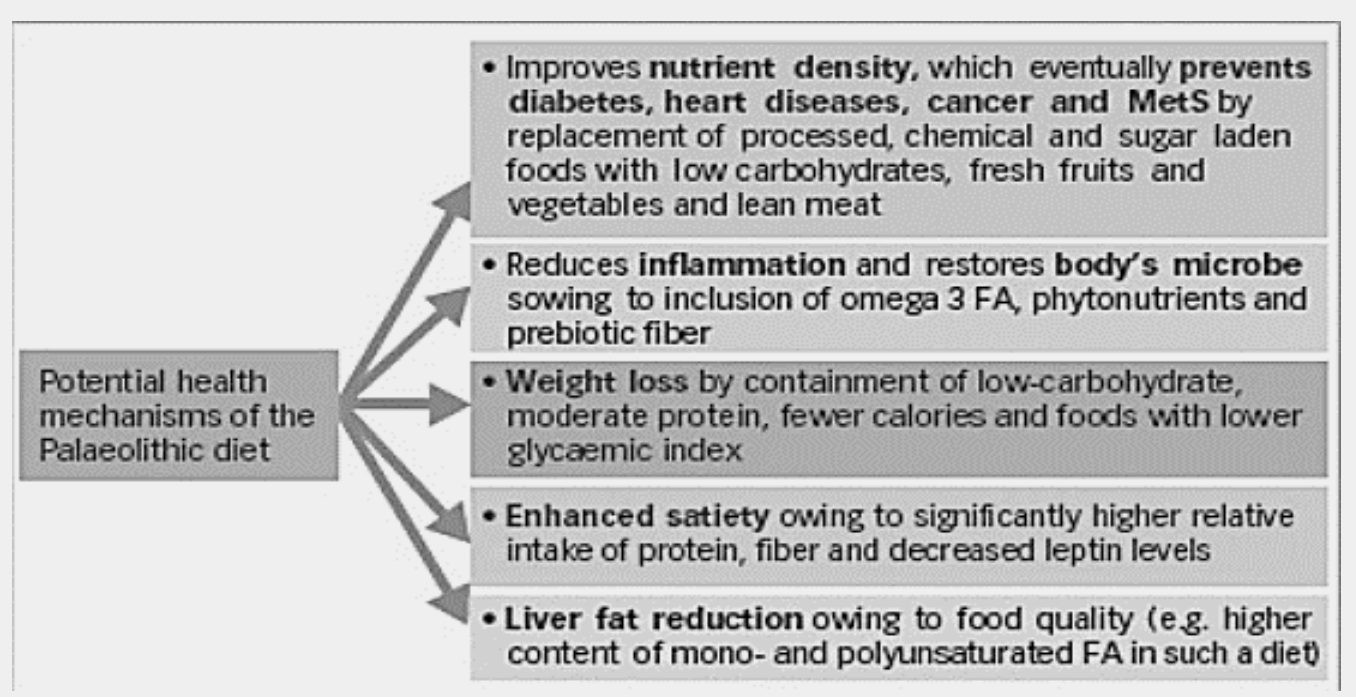

Figure 1: Potential impacts of Palaeolithic diet on various metabolic mechanisms (FA: Fatty acid, MetS: Metabolic Syndrome) [13]

Epidemiological studies data of large populations have suggested that MetS is related to an increased risk of cervical carcinoma. Timely diagnosis and proper management of the metabolic syndrome (MetS) is highly recommended as a strategy undertaken to control and cure gynaecologic cancer [14]. Paleodiet and variants have shown significant improvement in risks associated with MetS as determined from the decline in weight, C-reactive protein, glycated haemoglobin, improved blood pressure, glucose tolerance, insulin level, and lipid profiles [15]. Figure 1 provides summary of potential metabolic benefits of paleodiet as indicated in short-term randomized controlled trials.

\section{Comparative Analysis of Different Nutrient Interventions in Controlling MetS}

Table 3: Mean differences in impacts of two dietary interventions (PD vs NNR) in controlling MetS related risk factors. NNR is Nordic Nutrition Readings are recorded in the systematic review "Palaeolithic nutrition for metabolic syndrome: systematic review and meta-analysis" [10].

\section{Randomized Controlled Trial on Obese Post-Menopausal Women} (C. Mellberg, S. Sandberg, M. Ryberg, et al., 2014)

\begin{tabular}{|c|c|c|}
\hline $\begin{array}{l}\text { Metabolic Syndrome Risk Factors } \\
\text { (MetS) }\end{array}$ & $\begin{array}{c}\text { Paleo Diet } \\
\text { (PD Experimental) }\end{array}$ & $\begin{array}{c}\text { National Dietary Guidelines for Scandina- } \\
\text { vian Countries (NNR Control) }\end{array}$ \\
\hline 1. Mean decrease in Triglyceride & $-0.38 \mathrm{mmol} / \mathrm{l}$ & $-0.12 \mathrm{mmol} / \mathrm{l}$ \\
\hline Mean decrease in Waist Circumference & $-11.5 \mathrm{~cm}$ & $-6 \mathrm{~cm}$ \\
\hline 3. Mean decrease in Systolic BP & $-12.2 \mathrm{mmHg}$ & $-8.5 \mathrm{mmHg}$ \\
\hline 4. Mean reduction of Diastolic BP & $-6.6 \mathrm{mmHg}$ & $-5 \mathrm{mmHg}$ \\
\hline 5. Mean increase in HDL Cholesterol & $-0.05 \mathrm{mmol} / \mathrm{l}$ & $-0.04 \mathrm{mmol} / \mathrm{l}$ \\
\hline 6. Serum Glucose (fasting) & $-0.21 \mathrm{mmol} / \mathrm{l}$ & $0.05 \mathrm{mmol} / \mathrm{l}$ \\
\hline
\end{tabular}


Paleodiet efficacy as determined against different guidelinebased control diet plans, in various randomized controlled trials, was greater in eliciting short-term impacts on Metabolic Syndrome related five major factors. These broadly included waist circumference, blood pressure (systolic \& diastolic), serum glucose concentrations, triglycerides \& HDL cholesterol in fasting condition [10]. Table 3 provides clinical data of various MetS risk factors assessed after nutritional interventions given to post-menopausal women. Results indicate greater reduction of triglycerides, waist circumference and blood pressure. No significance reduction is observed in HDL cholesterol in both groups. Serum glucoses increase in control group is indicated by high carb diet.

\section{Discussion}

\section{Impact}

\section{Global Cancer Burden}

Today, among non-communicable diseases which are responsible for $82 \%$ of NCD related deaths globally, cancer alone contribute to $21.7 \%$ of it. As mortality rate is predicated to increase manifolds by 2030, according to the World Health Organization cancer might affect 12.6 million people annually [17]. Various indices which are used in measuring cancer burden include prevalence, incidence, fatality, and mortality [18]. These indices are used comprehensively by the International Agency for Research on Cancer (IARC) of the World Health Organization (WHO) in publishing global cancer statistics. The database is available online at CANCER Mondial website (http://www-dep. iarc.fr). This data is alarming and calls for urgent need to develop FDA approved, regional based, customized dietary plans to contain the progress of the disease.

\section{Prevalence of Gynaecologic Cancers}

Centres of Disease Control and Prevention provides information about five leading types of gynaecological cancers. The most common gynaecologic cancer in 2012-2016 was uterine cancer $(26.82$ cases per 100,000$)$ and the least common $(0.66$ per 100,000$)$ was vaginal cancer. The highest incidence rate $(9.60$ per 100,000) of cervical cancer was among Hispanic women. White women had the highest incidence rate $(27.16$ per 100,000$)$ of uterine, ovarian (11.50 per 100,000), and vulvar (2.80 per $100,000)$ cancer. The highest incidence rate $(0.90$ per 100,000$)$ of vaginal cancer was among black women [4]. The sixth type is fallopian tube cancer which is rarely found [19]. Women dietary habits have an immense role to play in their reproductive system health [1].

\section{Importance of Nutritional Interventions in Gynecologic Cancers}

Several evidence-based guidelines have been developed for reversing the effects of malnutrition in adult cancer patients by (ESPN) the European Partnership for Action Against Cancer, initiative at EU level [3]. For gynecological cancers, several nutritional interventions have been reported by randomized clinical trials between 2002-2015. Cervical benign, ovarian, and uterine cancer related early dietary treatment plans have been advised [20]. Table 4 summarizes some randomized clinical trials to estimate effectiveness of pre-treatment and post-treatment nutritional interventions in addition to other modes of treatment for gynae-oncology patients $[21,22]$.

Table 4: Randomized controlled trials of various nutritional interventions in gynaecological patients. These interventions include Early enteral feeding (pre-surgery) as compared to post surgery traditional oral feeding (Early Feeding After Gynaecologic Laparotomy and for the entire duration of hospital stay). QoL means Quality of life.

\begin{tabular}{|c|c|c|c|}
\hline Cancer Type & Nutritional Intervention & Benefits & Limitations \\
\hline $\begin{array}{l}\text { Epithelial Ovarian } \\
\text { Cancer } \\
\text { (EOC) }\end{array}$ & $\begin{array}{l}\text { Post-operative Enteral nutrition formula ( } 4.2 \mathrm{~kJ} / \mathrm{mL} \text { or } 1 \mathrm{kcal} / \\
\mathrm{mL} \text { ), fed through the nasojejunal tube, contains } 20 \% \text { protein, } \\
30 \% \text { fat and } 50 \% \text { carbs. Feeding rate of } 40 \mathrm{ml} / \mathrm{h} \text { at } 4 \mathrm{~h} \text { for } \\
\text { the first } 24 \mathrm{~h} \text {, were later increased to provide Post-operative } \\
\text { Enteral nutrition formula ( } 4.2 \mathrm{~kJ} / \mathrm{mL} \text { or } 1 \mathrm{kcal} / \mathrm{mL} \text { ), fed } \\
\text { through the nasojejunal tube, contains } 20 \% \text { protein, } 30 \% \text { fat } \\
\text { and } 50 \% \text { carbs. Feeding rate of } 40 \mathrm{ml} / \mathrm{h} \text { at } 4 \mathrm{~h} \text { for the first } 24 \\
\text { h, were later increased to provide nutrition of } 125 \mathrm{~kJ} / \mathrm{kg} \text { body } \\
\text { weight (adjusted for overweight patients). } \\
\text { Following daily assessment, Enteral feeding was stopped after } \\
\text { patients resume normal oral intake }(65-75 \% \text { of the daily } \\
\text { nutritional intake) [21]. }\end{array}$ & $\begin{array}{l}\text { Early Enteral feeding through } \\
\text { a nasojejunal tube may be } \\
\text { associated with improved } \\
\text { postoperative nutritional } \\
\text { status } 7 \text { days after surgery of } \\
\text { advanced EOC with moderate } \\
\text { to severe malnutrition. }\end{array}$ & $\begin{array}{l}\text { Possible complications } \\
\text { (aspiration of feeds and } \\
\text { subsequent chemical } \\
\text { pneumonitis, discomfort } \\
\text { and irritation, diarrhea). } \\
\text { May cost up to } \$ 10 \text { per } \\
\text { day for the feeds plus the } \\
\text { involvement of a nutrition } \\
\text { team) }\end{array}$ \\
\hline $\begin{array}{l}\text { Patients of } \\
\text { Endometrial, } \\
\text { ovarian, Fallopian } \\
\text { tube cancer } \\
\text { undergoing } \\
\text { intestinal resection }\end{array}$ & $\begin{array}{l}\text { Post-Operative Early oral (EOF) vs Traditional oral } \\
\text { feeding (TOF). } \\
\text { EOF group was given liquids, mineral water (no gas), tea, } \\
\text { chamomile infusion or apple juice, during the first } 24 \text { hours. } \\
\text { TOF group was switched to oral liquid diet for } 24 \text { h after } \\
\text { resumption of normal bowel function [22] }\end{array}$ & $\begin{array}{l}\text { Early resumption of oral food } \\
\text { intake is safe in this setting and } \\
\text { provides a significant reduction } \\
\text { in length of hospital stay }\end{array}$ & $\begin{array}{l}\text { EOF as the sole enhancer } \\
\text { of postoperative recovery } \\
\text { does not influence patient } \\
\text { well-being. Multimodal } \\
\text { plan is required to } \\
\text { enhance QoL score. }\end{array}$ \\
\hline
\end{tabular}




\section{Cancer Therapy \& Oncology International Journal}

\section{Limitations}

Due to a small volume of randomized clinical trials which are mostly conducted in developed countries, it is not yet sensible to draw a conclusion whether paleo diet must be added in multimodal treatment plans of gynecological cancers. In the same context, growing significance of paleo-oncology cannot be underestimated. Funded research projects and voluntary clinical research is the need of the hour to statistically evaluate the role of paleodiet in reducing gynecological cancer burden and improving reproductive health of women of all ethnicities.

\section{Future Directions}

FDA can implement a one-year research plan to bring into practice customized paleodiet charts for healthy individuals coming in for mammography or related clinical examinations. Later stage can expand the research volume to incorporate patients with risk to develop cancer and pre-malignant complications of gynaecology. It has now become a social responsibility as an immense volume of disinformation on social media platforms are urging laymen to self-experiment with pseudo-paleo nutrition which is yet another challenge to overcome in the domain of gynae-oncology.

\section{Author Contributions}

F.R. has contributed to drafting the manuscript, designed search strategy, and conducted informal research. F.H. has performed critical analysis and reviewed the manuscript.

\section{Acknowledgement}

We are thankful to Saeed Anwar Shah (MBBS, MPH) for his guidance in understanding different aspects of public health and hospital administration related to our topic.

\section{Disclosure Statement}

Authors have not reported any potential conflict of interest.

\section{Funding}

No funding is provided by any public or private institute.

\section{References}

1. O Andreas, S Marko, Liz Isenring, Monika Janda (2017) Nutrition interventions in patients with gynecological cancers requiring surgery. Gynecologic Oncology 145(1): 192-199.

2. Cantrell LS (2015) Nutrition in Gynecologic Cancer. Gynecologic Oncology 4: 265-271.

3. A Jann, B Patrick, Vickie Baracos, Nicole Barthelemy, Hartmut Bertz, et al. (2017) ESPEN guidelines on nutrition in cancer patients. Clin Nutr 36(1): 11- 48.

4. U.S. Cancer Statistics Data Briefs, No. 11 (2019) Gynecologic Cancer Incidence, United States-2012-2016. Centres for Disease Control and
Prevention, United States Cancer Statistics (USCS).

5. World Health Organization (2018) Cancer Fact Sheet.

6. Molto E S, Peter Sheldrick (2018) Paleo-oncology in the Dakhleh Oasis, Egypt: Case studies and a paleoepidemiological perspective. Int J Paleopathol 21: 96-110.

7. Halperin EC (2004) Paleo-Oncology: The Role of Ancient Remains in the Study of Cancer. Perspect Biol Med 47(1): 1-14.

8. Greaves M, Luca E (2015) Evolutionary Adaptations to Risk of Cancer: Evidence from Cancer Resistance in Elephants. JAMA 314(17): 18061807.

9. David AZ (2010) Cancer: an old disease, a new disease or something in between? Nat Rev Cancer 10: 728-733.

10. Manheimer EW, van Zuuren EJ, Fedorowicz Z, Pijl H (2015) Paleolithic nutrition for metabolic syndrome: systematic review and metaanalysis. The American Journal of Clinical Nutrition, 102(4): 922-932.

11. T Csaba, S Mária, C Zsófia (2018) Complete Cessation of Recurrent Cervical Intraepithelial Neoplasia (CIN) by the Paleolithic Ketogenic Diet: A Case Report. Journal of Cancer Research and Treatment 6(1): $1-5$.

12. C Mellberg, S Sandberg, M Ryberg, M Eriksson, S Brage, et al. (2014) Long-term effects of a Palaeolithic-type diet in obesepostmenopausal women: a 2-year randomized trial. Eur J Clin Nutr 68(3): 350-357.

13. Gupta L, Deepak K, Priti RL, Sanjay K, Deep D (2019) Palaeolithic Diet in Diabesity and Endocrinopathies - A Vegan's Perspective. Eur Endocrinol 15(2): 72-82.

14. Lee DY, Lee TS (2020) Associations between metabolic syndrome and gynecologic cancer. Obstet Gynecol Sci 63(3): 215-224.

15. Seema Patel, Hafiz AR Suleria (2017) Ethnic and paleolithic diet: Where do they stand in inflammation alleviation? A discussion. Journal of Ethnic Foods 4(4): 236-241.

16. Kathryn J Hunt, Charlotte Roberts, Casey Kirkpatrick (2018) Taking stock: A systematic review of archaeological evidence of cancers in human and early hominin remains, Int J Paleopathol 21: 12-26.

17. World Health Oganization (2018) Cervical Cancer.

18. R Sankaranarayanan, J Ferlay (2006) Worldwide burden of gynecological cancer: The size of the problem. Best Pract Res Clin Obstet Gynaecol 20(2): 207-225.

19. Centres for Disease Control and Prevention (2020) Gynecologic Cancers. Retrieved from Division of Cancer Prevention and Control, Centers for Disease Control and Prevention.

20. Michael L Pearl, F Martina, M Linda, Fidel A Valea, Paul A DiSilvestro, Eva Chalas et al. (2002) A randomized controlled trial of a regular diet as the first meal in gynecologic oncology patients undergoing intraabdominal surgery. Obstetrics \& Gynecology 100(2): 230-234.

21. B Jannah, J Monika, G Nick, Judy Bauer, Merrilyn Banks, et al. (2015) Quality of life after early enteral feeding versus standard care for proven or suspected advanced epithelial ovarian cancer: Results from a randomised trial. Gynecologic Oncology 137(3): 516-522.

22. L Minig, R Biffi M, V Zanagnolo, A Attanasio, C Beltrami, et al. (2009) Early Oral Versus "Traditional" Postoperative Feeding in Gynecologic Oncology Patients Undergoing Intestinal Resection: a Randomized Controlled Trial. Ann Surg Oncol 16(6): 1660-1668. 
Your next submission with Juniper Publishers will reach you the below assets

- Quality Editorial service

- Swift Peer Review

- Reprints availability

- E-prints Service

- Manuscript Podcast for convenient understanding

- Global attainment for your research

- Manuscript accessibility in different formats

( Pdf, E-pub, Full Text, Audio)

- Unceasing customer service

Track the below URL for one-step submission https://juniperpublishers.com/online-submission.php 